\title{
EFEKTIVITAS PEMBELAJARAN TEAM ACCELERATED INSTRUCTION TERHADAP KEMAMPUAN MEMECAHKAN MASALAH MATEMATIKA SISWA KELAS VIII SMP KOTA JOGJAKARTA
}

\author{
Sri Adi Widodo \\ Pendidikan Matematika, Universitas Sarjanawiyata Tamansiswa \\ J1. Batikan UH III/1043 Tuntungan Tahunan Yogyakarta \\ E-mail: dodok_chakep@yahoo.com
}

\begin{abstract}
ABSTRAK
Tujuan penelitian adalah untuk mengetahui model pembelajaran yang efektif digunakan pada pembelajaran matematika, Team Accelerated Instruction atau Model Pembelajaran Langsung. Jenis Penelitian ini adalah eksperimen semu dengan 3667 siswa sebagai sampel penelitian. Variabel penelitian adalah kemampuan memecahkan masalah matematika, kemampuan awal dan model pembelajaran. Metode pengumpulan data yang digunakan adalah metode tes. Teknik analisis data yang digunakan adalah uji analisis variansi. Dapat disimpulkan bahwa Team Accelerated Instruction lebih efektif digunakan daripada Model Pembelajaran Langsung.
\end{abstract}

Keyword: Efektivitas, Team Accelerated Instruction, Kemampuan Memecahkan Masalah.

\begin{abstract}
The aim of the research was to know the learning model that was effective was used, Team Accelerated Instruction or direct instruction. This research was the quasi experiment with 367 students as the sample of the research. Variable of the research was the capacity to problem solving in mathematics, the initial capacity and the learning model. The method used was the test method. Data analysis used was the analysis variance test. It could be concluded that Team Accelerated Instruction more effective was used than direct instrucction
\end{abstract}

Keyword: effectiveness, Team Accelerated Instruction, capacity of problem solving.

\section{Pendahuluan}

Dalam pendidikan matematika, pemecahan masalah menjadi hal yang penting untuk ditanamkan pada diri peserta didik. Dengan pemecahan masalah matematika, membuat matematika tidak kehilangan maknanya, sebab suatu konsep atau prinsip akan bermakna kalau dapat diaplikasikan dalam pemecahan masalah. Seperti yang diungkapkan oleh E. Mulyasa dalam Aries Yuwono (2010: 13), yang menyatakan bahwa pemecahan masalah memegang peranan penting terutama agar pembelajaran dapat berjalan dengan fleksibel.

Dalam dunia pendidikan matematika, permasalahan matematika biasanya berbentuk pertanyaan atau soal matematika yang harus dijawab atau 
dikerjakan oleh responden (peserta didik). Suatu soal matematika dapat menjadi masalah matematika jika peserta didik tidak mempunyai gambaran untuk menyelesaikan permasalahan, tetapi peserta didik tersebut berkeinginan untuk menyelesaikan masalah matematika tersebut.

$$
\text { Polya (1973: } 154 \quad-\text { 157), }
$$
menyatakan bahwa masalah dalam matematika dikelompokkan menjadi 2 jenis yaitu (1) problem to find atau soal mencari dan (2) problem to prove atau soal membuktikan. Yang dimaksud dengan soal mencari adalah mencari, menentukan, atau mendapatkan nilai tertentu yang tidak diketahui dalam soal dan memenuhi kondisi atau syarat tertentu. Sedangkan soal membuktikan adalah prosedur untuk menentukan apakan suatu pernyataan benar atau tidak benar. Dalam penelitian ini masalah matematika yang digunakan adalah masalah berbentuk mencari atau problem to find. Hal ini dikarenakan karakteristik peserta didik kelas VIII SMP yang ratarata masih berusia 14 tahun, walaupun pada tahap perkembangannya sudah memasuki fase formal tetapi pola pikir formal siswa SMP kelas VIII masih belum sempurna. Dengan kata lain siswa kelas VIII SMP masih perlu beradaptasi dari pola piker konkrit ke pola fikir formal atau abstrak.

Menurut Polya (1973: 5 - 19), langkah-langkah untuk menyelesaikan masalah matematika adalah memahami masalah, merencanakan masalah, merencanakan untuk menyelesaikan masalah dan memeriksa kembali jawaban.

Pada memahami masalah, pada tahap ini masalah harus diyakini. Untuk menyakini suatu permasalahan dapat dilakukan dengan beberapa cara, diantaranya adalah dengan membaca berulang-ulang, menanyakan pada diri sendiri tentang apa yang ketahui, apa yang tidak diketahui, dan menanyakan tujuan dari permasalahan matematika. Pada tahap membuat rencana, pada tahap ini untuk membuat rencana menyelesaikan permasalahan dapat dilakukan dengan mencari hubungan antara data (informasi) yang diketahui dengan yang tidak diketahui. Dimungkinkan pada tahap ini melakukan perhitungan pada variabel yang tidak diketahui tersebut.sehingga akan memperoleh pertanyaan bagaimana informasi yang telah diketahui akan saling dihubungkan untuk memperoleh hal-hal yang tidak diketahui.

Pada tahap melaksanakan rencana, pada tahapan ini peserta didik akan memeriksa tiap-tiap langkah yang tertuang dalam rencana dan menuliskannya secara detail untuk memastikan bahwa tiap-tiap langkah tersebut sudah benar. Sedangkan pada tahao memeriksa kembali jawaban, pada tahapan terakhir ini, peserta didik akan 
melihat kembali jawabannya untuk menyakinkan bahwa hasil jawaban dari permasalahan tersebut sudah benar.

Wina Sanjaya (2008: 179) menyatakan bahwa model pembelajaran langsung adalah pembelajaran yang menekankan pada proses penyampaian materi secara verbal dari seorang guru kepada sekelompok siswa dengan maksud siswa menguasai materi secara optimal. Sehingga orang lebih mengidentikkan dengan model ceramah. Karakteristik model pembelajaran langsung diantaranya (1) dilakukan dengan menyampaikan materi secara verbal, (2) materi yang disampaikan guru adalah materi yang sudah jadi, (3) tujuan utama pembelajaran adalah untuk penguasaan materi.

Pada model pembelajaran langsung guru karena tidak harus terus menerus bicara, tetapi guru diperbolehkan berbicara pada awal pelajaran, menerangkan materi dan contoh soal pada waktu-waktu yang diperlukan saja. Dalam model pembelajaran langsung peserta didik tidak hanya mendengar dan membuat catatan. Guru bersama peserta didik berlatih menyelesaikan soal latihan dan bertanya kalau belum mengerti. Guru dapat menjelaskan pekerjaan peserta didik secara individual atau klasikal.

Model pembelajaran langsung memiliki kecenderungan bahwa (1) siswa yang mempunyai kemampuan mendengar dan menyimak akan lebih diuntungkan dibandingkan dengan siswa yang mempunyai kemampuan lain, (2) tidak mampu melayani perbedaan tiap-tiap individu baik perbedaan kemampuan, pengetahuan, minat, bakat serta gaya belajar, (3) keberhasilan model ini sangat tergantung pada kesiapan seorang guru dalam menyampaikan materi, kesempatan untuk mengontrol pemahaman siswa sangat terbatas karena gaya komunikasi pada model ini lebih cenderung satu arah (Wina Sanjaya, 2008: 191).

Tenaga pendidik mempunyai peran yang penting dalam sistem pembelajaran terutama peningkatan kualitas pembelajaran. Untuk menarik minat belajar mahasiswa guru harus menggunakan model pembelajaran selain model pembelajaran pembelajaran langung. Sehingga pembelajaran yang menggunakan model pembelajaran langsung dapat menyebabkan mahasiswa merasa bosan. Hal ini dikarenakan pada model pembelajaran langsung pola komunikasi berjalan satu arah sehingga mahasiswa merasa tidak terlibat secara langsung dalam pembelajaran.

$$
\text { Erman Suherman }
$$
menyatakan bahwa model pembelajaran Team Accelerated Instruction (TAI) memiliki karakteristik tanggung jawab belajar berada pada siswa. Sehingga, siswa harus membangun pengetahuan sendiri dan tidak hanya menerima bentuk 
jadi dari guru. Selain itu pola komunikasi guru-siswa adalah negosiasi dan bukan imposisi-intruksi. Hal senada diungkapkan oleh Slavin (1995: 97 - 98), tujuan dari model pembelajaran TAI adalah untuk mengadaptasi pengajaran terhadap perbedaan individu yang berkaitan dengan kemampuan awal siswa maupun pencapaian prestasi siswa.

$\begin{array}{llr}\text { Secara } & \text { umum Slavin (1992) } \\ \text { mengatakan bahwa dalam mode } \\ \text { pembelajaran }\end{array}$
berbeda. Anggota dalam satu kelompok saling membantu satu sama lain, bekerjasama untuk menjawab permasalahan pada lembar jawab dan mendiskusikannya jika ada permasalahan. Tes akhir dilakukan secara individu, siswa tidak diperkenankan untuk saling membantu dan nilai yang telah diperoleh diperhatikan oleh siswa.

Berdasarkan permasalahan tersebut maka tujuan dalam penelitian ini adalah Untuk mengetahui model pembelajaran yang efektif digunakan pada pembelajaran matematika, Team Accelerated Instruction (TAI) atau Model Pembelajaran Langsung.

\section{Metode Penelitian}

Sesuai dengan permasalahan yang akan diteliti, maka jenis penelitian ini termasuk dalam penelitian eksperimen semu (quasi-experimental research). Penelitian ini bermaksud memberikan perlakuan pada sampel, selanjutnya peneliti ingin mengetahui keefektifan terhadap masing-masing perlakuan. Perlakuan yang dimaksud adalah penggunaan model pembelajaran Team Accelerated Instruction (TAI) dan model pembelajaran langsung (MPL) untuk pembelajaran matematika SMP pada pokok bahasan garis singgung lingkaran. Penelitian dilakukan di Yogyakarta dengan mengambil enam (6) Sekolah Menengah Pertama (SMP) baik negeri maupun swasta. Penelitian ini berlangsung selama 6 (enam) bulan

Suharsimi Arikunto (2002: 108) menyatakan bahwa populasi adalah keseluruhan subyek penelitian. Sehingga dalam penelitian ini populasinya adalah seluruh siswa kelas VIII SMP baik SMP Negeri maupun SMP swasta se-kota Yogyakarta Tahun Pelajaran 2014 2015. SMP yang terletak di kota Yogyakarta berjumlah 57 sekolah yang terdiri dari 16 SMP negeri dan 41 SMP swasta. Dengan menganggap bahwa sekolah negeri dan sekolah swasta memiliki karakteristik kemampuan yang relatif sama maka pengambilan sampel yang digunakan dalam penelitian ini adalah teknik cluster random sampling. Adapun sekolah yang dijadikan tempat penelitian ini adalah SMP tersebut adalah SMP Negeri 4 Yogyakarta, SMP N 10 Yogyakarta, SMP N 11 Yogyakarta, SMP N 13 Yogyakarta, SMP Muhamadiyah 5 Yogyakarta, SMP Muhamadiyah 7 
Yogyakarta. Selanjutnya keenam sekolah tersebut dirandom kembali dengan menggunakan teknik cluster random sampling kembali untuk memperoleh dua kelas yang digunakan sebagai sampel penelitian.

Untuk melihat apakah kelompok kontrol dan kelompok ekperimen memiliki kondisi yang sama maka kedua kelompok tersebut perlu dilakukan uji keseimbangan antara kelompok kontrol dan kelompok ekperimen. Setelah dilakukan perhitungan secara manual diperoleh bahwa Variansi Total $\left(\mathrm{S}_{\mathrm{p}}\right)$ sebesar 77,07 dan hasil uji t hitung ( $\left.\mathrm{t}_{\mathrm{obs}}\right)$ sebesar $-0,032$. Sedangkan $t$ tabel $\left(\mathrm{t}_{\mathrm{tab}}\right)$ pada $v=367$ untuk taraf signifikasi 5\% adalah 1,960, sehingga diperoleh bahwa daerah kritiknya (DK) atau daerah untuk menolak $\mathrm{H}_{0}$ adalah $\{\mathrm{t} \mid \mathrm{t}<-1,960$ atau $\mathrm{t}$ $>1,960\}$. Berdasarkan hal tersebut maka dapat diputuskan bahwa t hitung $\left(\mathrm{t}_{\mathrm{obs}}\right)$ tidak berada pada daerah kritik atau $\mathrm{t}_{\mathrm{obs}} \notin$ DK, sehingga dapat disimpulkan bahwa sampel pada kelompok kontrol dan kelompok eksperimen berada dalam keadaan seimbang atau dengan kata lain secara statistik keadaan kelompok kontrol dan kelompok eksperimen mempunyai kemampuan yang sama.

Dalam penelitian ini yang menjadi variabel terikat adalah kemampuan memecahkan masalah matematika. Kemampuan memecah masalah matematika suatu kemampuan yang dimiliki oleh peserta didik untuk menyelesaikan masalah matematika yang dihadapi dengan menggunakan semua pengetahuan matematika yang dimilikinya. Indikator dalam memecahkan masalah adalah (1) Peserta didik dapat memahami masalah, (2) Peserta didik dapat meencanakan untuk menyelesaikan masalah, (3) Peserta didik dapat mealaksanakan rencana untuk menyelesaikan masalah, dan (4) Peserta didik melakukan pemeriksaan hasil jawaban soal terhadap soal. Sedangkan variabel bebas adalah kemampuan awal siswa dan model pembelajaran. Adapun desain penelitian seperti pada tabel 1 .

Tabel 1. Desain Penelitian

\begin{tabular}{ccccc}
\hline & & \multicolumn{3}{c}{ Kemampuan Awal (b) } \\
\cline { 3 - 5 } & & Tinggi $\left(b_{1}\right)$ & Sedang $\left(b_{2}\right)$ & Rendah $\left(b_{3}\right)$ \\
Model Pembelajaran & TAI $\left(a_{1}\right)$ & $(a b)_{11}$ & $(a b)_{12}$ & $(a b)_{13}$ \\
\cline { 2 - 5 }$($ a) & MPL $\left(a_{2}\right)$ & $(a b)_{21}$ & $(a b)_{22}$ & $(a b)_{23}$ \\
\hline
\end{tabular}

Metode tes digunakan untuk mengumpulkan data kemampuan awal dan kemampuan memecahkan masalah matematika pada pokok bahasan lingkaran. Tes Kemampuan Awal (TKA) digunakan untuk mengetahui sejauhmana kemampuan peserta didik terhadap materi yang dijadikan sebagai persyaratan untuk 
mempelajari garis singgung lingkaran.

Tes kemampuan awal dibuat berbentuk pilihan ganda dan mengacu pada materi yang mempengaruhi dalam mempelajari garis singgung lingkaran. Adapun materi yang mempengaruhi atau materi prasyarat dalam mempelajari garis singgung lingkaran diantaranya adalah operasi hitung dasar, Operasi pangkat dan akar, keliling lingkaran, dan teorema phytagoras. Penyekoran Tes kemampuan awal adalah memberikan skor 1 (satu) untuk jawaban benar dan skor 0 (nol) untuk jawaban salah. Sedangkan Tes
Pemecahan Masalah Matematika (TPMM) digunakan untuk mengetahui sejauhmana kemampuan peserta didik dalam memecahkan masalah matematika pada pokok bahasan garis singgung lingkaran. TPMM berbentuk uraian atau essay yang mengacu pada indikator yang telah ditentukan yaitu (1) panjang garis singgung, (2) jarak dua lingkaran, (3) luas bangun yang terbentuk dari garis singgung. Pedoman atau rubrik penyekoran TPMM disajikan seperti pada tabel 2.

Tabel 2. Rubrik Penyekoran Tes Pemecahan Masalah Matematika

\begin{tabular}{|c|c|c|}
\hline Tahapan Polya & Skor & Indikator penyekoran \\
\hline \multirow{4}{*}{$\begin{array}{l}\text { Memahami } \\
\text { Masalah }\end{array}$} & 3 & $\begin{array}{l}\text { Siswa mampu menuliskan (mengungkapkan) apa yang diketahui dan } \\
\text { ditanyakan dari masalah yang diajukan dengan jelas }\end{array}$ \\
\hline & 2 & $\begin{array}{l}\text { Siswa hanya menuliskan (mengungkapkan) apa yang diketahui atau } \\
\text { apa yang ditanyakan saja }\end{array}$ \\
\hline & 1 & $\begin{array}{l}\text { siswa menuliskan data/konsep/pengetahuan yang tidak berhubungan } \\
\text { dengan masalah yang diajukan sehingga siswa tidak memahami } \\
\text { masalah yang diajukan }\end{array}$ \\
\hline & 0 & $\begin{array}{l}\text { siswa tidak menuliskan apapun sehingga siswa tidak memahami } \\
\text { makna dari masalah yang diajukan }\end{array}$ \\
\hline \multirow{3}{*}{$\begin{array}{l}\text { Merencanakan } \\
\text { Menyelesaikan }\end{array}$} & 2 & $\begin{array}{l}\text { Siswa menuliskan syarat cukup dan syarat perlu (rumus) dari } \\
\text { masalah yang diajukan serta menggunakan semua informasi yang } \\
\text { telah dikumpulkan }\end{array}$ \\
\hline & 1 & $\begin{array}{l}\text { siswa menceritakan/menuliskan langkah langkah } \\
\text { menyelesaikan masalah tetapi tidak runutu }\end{array}$ \\
\hline & 0 & $\begin{array}{l}\text { siswa tidak menceritakan/menulis langkah-langkah untuk } \\
\text { menyelesaikan masalah }\end{array}$ \\
\hline \multirow{5}{*}{$\begin{array}{l}\text { Melaksanakan } \\
\text { rencana }\end{array}$} & 4 & $\begin{array}{l}\text { Siswa melaskanakan rencana yang telah dibuat, menggunakan } \\
\text { langkah-langkah menyelesaikan masalah secara benar, tidak terjadi } \\
\text { kesalahan prosedur, dan tidak terjadi } \\
\text { algoritma/perhitungan }\end{array}$ \\
\hline & 3 & $\begin{array}{l}\text { Siswa melaskanakan rencana yang telah dibuat, menggunakan } \\
\text { langkah-langkah menyelesaikan masalah secara benar, dan tidak } \\
\text { terjadi kesalahan prosedur, tetapi terjadi kesalahan } \\
\text { algoritma/perhitungan }\end{array}$ \\
\hline & 2 & $\begin{array}{l}\text { Siswa melaksanakan rencana yang telah dibuat, tetapi terjadi } \\
\text { kesalahan prosedur }\end{array}$ \\
\hline & 1 & $\begin{array}{l}\text { Siswa melaksanakan rencana yang telah dibuat, tetapi terjadi } \\
\text { kesalahan prosedur dan kesalahan algoritma/perhitungan }\end{array}$ \\
\hline & 0 & Siswa tidak mampu melaksanakan rencana yang telah dibut \\
\hline \multirow{2}{*}{$\begin{array}{l}\text { Memeriksa } \\
\text { kembali }\end{array}$} & 1 & Siswa melakukan pemeriksaan kembali jawaban \\
\hline & 0 & Siswa tidak melakukan pemeriksanaan kembali jawaban \\
\hline
\end{tabular}




\section{Hasil Dan Pembahasan}

Setelah pembelajaran TAI dan Model Pembelajaran Langsung serta telah diberikan tes pemecahan masalah kemudian dilakukan uji anava dua jalan sel tak sama. Uji ini dilakukan setelah uji prasyarat Anava terpenuhi. Adapun uji prasyarat anava adalah (1) sampel yang diambil berasal dari populasi berdistribusi normal dan (2) variansi dari sejumlah populasi berdistribusi normal.

Uji normalitas digunakan untuk mengetahui apakah sampel berasal dari populasi yang berdistribusi normal. Uji normalitas yang digunakan dalam penelitian ini adalah Uji Lilliefors dengan taraf signifikansi 5\%. Berdasarkan data kemampuan memecahkan masalah matematika siswa kelompok eksperimen, diperoleh bahwa jumlah siswa $(n)=177$, dengan rerata $=21,63$ dan standar deviasi sebesar 5,37. Setelah dilakukan perhitungan diperoleh bahwa nilai $\mathrm{L}_{\text {mak }}$ sebesar 0,063. Sedangkan L tabel untuk n $=177$ pada taraf signifikansi $5 \%\left(\mathrm{~L}_{\mathrm{tab}}\right)$ adalah 0,067 . Sehinggga daerah kritiknya (DK) berada pada $\{L \mid L>0,067\}$. Berdasarkan hal tersebut, maka dapat diputuskan bahwa $\mathrm{L}_{\mathrm{obs}}$ tidak berada pada daerah kritik akibatnya $\mathrm{H}_{0}$ diterima. Sehingga dapat disimpulkan bahwa siswa pada kelompok eksperimen berasal dari populasi yang berdistribusi normal.

$$
\text { Sedangkan untuk data }
$$

kemampuan memecahkan masalah matematika siswa kelompok kontrol, diperoleh bahwa jumlah siswa $(n)=192$, dengan rerata $=19,50$ dan standar deviasi sebesar 5,05. Setelah dilakukan perhitungan diperoleh bahwa nilai $\mathrm{L}_{\mathrm{mak}}$ sebesar 0,057. Sedangkan L tabel untuk n $=192$ pada taraf signifikansi 5\% ( $\left.\mathrm{L}_{\mathrm{tab}}\right)$ adalah 0,064, sehinggga daerah kritiknya (DK) berada pada $\{L \mid L>0,064\}$. Berdasarkan hal tersebut, maka dapat diputuskan bahwa $\mathrm{L}_{\mathrm{obs}}$ tidak berada pada daerah kritik akibatnya $\mathrm{H}_{0}$ diterima. Sehingga dapat disimpulkan bahwa siswa pada kelompok kontrol berasal dari populasi yang berdistribusi normal.

Uji homogenitas bertujuan untuk mengetahui apakah variansi-variansi dari sejumlah populasi sama atau tidak. Dalam penelitian ini uji homogenitas variansi yang digunakan adalah uji Barlett. Setelah dilakukan perhitungan uji homogenitas varian berdasarkan kelompok model pembelajaran diperoleh bahwa $\chi^{2}$ hitung $\left(\chi_{\text {obs }}^{2}\right)$ adalah 0,675. Sedangkan $\chi^{2}$ tabel untuk $\mathrm{k}=1$ pada taraf signifikansi $5 \% \quad\left(\chi_{\text {tab}}^{2}\right)$ adalah 3,841, sehinggga daerah kritiknya (DK) berada pada $\left\{\chi^{2} \mid \chi^{2}>3,841\right\}$. Berdasarkan hal tersebut, maka dapat diputuskan bahwa $\chi^{2}{ }_{\text {obs }}$ tidak berada pada daerah kritik akibatnya $\mathrm{H}_{0}$ diterima. Sehingga dapat disimpulkan bahwa kemampuan siswa dalam memecahkan masalah matematika berdasarkan model pembelajaran mempunyai variansi yang sama.

Hasil perhitungan analisis variansi dua jalan dengan sel tak sama diperoleh 
bahwa $\mathrm{F}_{\text {obs }}$ sebesar 12,46 sedangkan $\mathrm{F}_{\text {tab }}$ pada taraf signifikansi 5\% sebesar 3,84. Berdasarkan tabel tersebut maka $\mathrm{F}_{\mathrm{obs}}>$ $F_{\text {tab }}$ sehingga dapat disimpulkan bahwa ada perbedaan efek antar model pembelajaran terhadap kemampuan siswa dalam memecahkan masalah matematika. Dengan kata lain kedua model pembelajaran (TAI dan MPL) memberikan pengaruh yang berbeda terhadap kemampuan siswa dalam memecahkan masalah matematika.

Tabel 3. Rataan dan Rataan Marginal

\begin{tabular}{ccccc}
\hline Kemampuan awal & Rendah & Sedang & Tinggi & $\begin{array}{c}\text { Rataan } \\
\text { Marginal }\end{array}$ \\
$\begin{array}{l}\text { Model } \\
\text { Pembelajaran }\end{array}$ & & & & \\
\hline TAI & 20,16 & 22,38 & 21,57 & 21,63 \\
MPL & 18,64 & 20,16 & 19,21 & 19,50 \\
\hline Rataan Marginal & 19,32 & 21,17 & 20,44 & \\
\hline
\end{tabular}

Uji komparasi ganda (uji pasca anava) adalah tindak lanjut dari analisis variansi (anava). Uji komparasi ganda dilakukan jika uji anava dua jalan sel tak sama tersebut belum diketahui model pembelajaran mana yang berpengaruh terhadap kemampuan memecahkan masalah matematika. Uji pasca anava antar model pembelejaran tidak perlu dilakukan uji. Hal ini dikarenakan variabel pada model pembelajaran hanya ada dua yaitu model pembelajaran Team Accelerated Instruction (TAI) dan Model Pembelajaran Langsung (MPL).

Berdasarkan rataan marginal (tabel 3) pada siswa yang diberi perlakuan dengan model pembelajaran TAI adalah 21,63 sedangkan pada siswa yang diberi perlakuan MPL adalah 19,50 sehingga dapat disimpulkan bahwa kemampuan memecahkan masalah matematika pada siswa yang menggunakan model pembelajaran TAI lebih baik jika dibandingkan dengan siswa-siswa yang menggunakan MPL. Dengan demikian dapat disimpulan bahwa secara umum model pembelajaran Team Accelerated Instruction (TAI) menghasilkan kemampuan memecahkan masalah matematika lebih baik daripada Model Pembelajaran Langsung (MPL) pada garis singgung lingkaran. Hal ini disebabkan karena model pembelajaran TAI mempunyai beberapa kelebihan diantaranya adanya bimbingan yang dilakukan oleh guru atau siswa dengan siswa dengan kemampuan awal tinggi pada masing-masing individu dalam di dalam kelompok melalui diskusi menyelesaikan permasalahan matematika. Sehingga siswa yang mempunyai kemampuan awal rendah atau sedang akan meningkatkan 
ketrampilan dan kemampuannya daalam mempelajari matematika.

Menurut Heru Kurniawan (2012: MP-370) efektivitas pembelajaran adalah proses pembelajaran yang mencapai hasil belajar sesuai dengan tujuan pembelajaran yang telah ditetapkan. Salah satu indikator indikator efektivitas hasil belajar adalah nilai yang dapat diperoleh dari nilai tes (aspek kognitif).

Triyanto

(2009:

mengungkapkan bahwa suatu pembelajaran dikatakan efektif apabila memenuhi persyaratan utama keefektifan, yaitu (1) presentasi waktu belajar siswa yang tinggi dicurahkan terhadap kegiatan belajar mengajar, (2) rata-rata perilaku melaksanakan tugas yang tijjnggi diantara siswa, (3) ketetapan antara kandungan materi ajaran dengan kemampuan siswa diutamakan, dan (4) mengembangkan suasana belajar yang akrab dan positif. Untuk mengukur keefektifan suatu pembelajaran dapat dilakukan dengan memberikan tes kepada peserta didik. Hal ini dikarenakan tes dapat digunakan untuk melakukan evaluasi berbagai aspek pengajaran.

Hal yang sama juga diungkapkan oleh Reigeluth dan Merrill (1979) yang menyatakan bahwa pengukuran keefektifan pembelajaran harus selalu dikaitkan dengan pencapaian tujuan pembelajaran. Salah satu indikator yang dapat dipakai untuk menetapkan keefektifan pembelajaran adalah kecermatan penguasaan perilaku. Kecermatan penguasaan perilaku yang dipelajari, juga sering disebut dengan tingkat kesalahan unjuk kerja, dapat dipakai sebagai indikator untuk menetapkan keefektifan pembelajaran. Makin cermat siswa menguasai perilaku yang dipelajari, makin efektif pembelajaran yang telah dijalankan dengan ungkapan lain, makin kecil tingkat kesalahan, berarti makin efektif pembelajaran.

Merujuk pada ketiga pendapat ahli tersebut, efektitifas pembelajaran dapat diukur dengan memberikan seperangkat tes kepada peserta didik. Tes tersebut digunakan untuk mengukur sejauhmana kecakapan peserta didik atau penguasaan materi peserta didik dalam memahami matematika. Karena salah satu objek penelitian ini adalah kemampuan siswa dalam memecahkan masalah matematika, maka kecakapan atau kompetensi yang yang harus dimiliki adalah peserta didik mampu untuk menyelesaikan atau memecahkan permasalahan matematika yang dihadapi oleh peserta didik.

\section{Kesimpulan}

Efektivitas pembelajaran dapat dilihat dengan cara memberikan tes prestasi atau tes kognitif kepada siswa. Berdasarkan uji anava dua jalan sel tak sama diperoleh bahwa ada perbedaan kemampuan memecahkan masalah 
matematika dengan kata lain ada perbedaan efek dari model pembelajaran yang diberikan kepada siswa. Dengan melihat rerata kemampuan memecahkan masalah matematika maka dapat disimpulkan bahwa model pembelajaran Team Accelerated Instruction (TAI) lebih efektif digunakan daripada Model Pembelajaran Langsung (MPL).

\section{Pustaka}

Aries Yuwono. 2010. Profil Siswa SMA Dalam Memecahkan Masalah Masalah Matematika Ditinjau Dari Tipe Kepribadian. Thesis. Surakarta: Universitas Sebelas Maret.

Budiyono. 2003. Metodologi Penelitian Pendidikan. Solo: UNS Press.

Budiyono. 2004. Statistika Untuk Penelitian. Solo: UNS Press

Cohn, Robert. 2008. Team Accelerated Instruction: A Cooperative Approach to Volume. Diunduh dari http://www.trincoll.edu tanggal 26 November 2008.

Erman Suherman. 27 Mei 2009. Model Belajar dan Pembelajaran Berorientasi Kompetensi Siswa. EDUCARE: Jurnal Pendidikan dan Budaya. Diunduh dari http://educare.e-fkipunla.net tanggal 25 Mei 2009
Heru Kurniawan. 2012. Upaya Peningkatan Fektivitas Pembelajaran Matematika Melalui Model Pembelajaran Kooperatif Tipe Team Assisted Individualization (TAI) Pada Siswa Kelas $V$ SD Negeri Sidomulyo Tahun Pelajaran 2011/2012. Prosiding Seminar Nasional Matematika dan Pendidikan Matematika. Yogyakarta: UNY.

Polya, G. 1973. How To Solve it: A New Aspect of Mathematical Method. New Jersey, USA: Pricenton University Press.

Slavin, R. E. 1992. Cooperative Learning. Diunduh dari http://www.uleth.ca pada tanggal 30 Maret 2009.

Slavin, R.E. 1995. Cooperativ Learning: Theory, Research and Practice, 2th edition. Englewood Cliffs, New Jersey, USA: Prentice Hall.

Suharsimi Arikunto. 2002. Prosedur Penelitian. Jakarta: Rineka Cipta Triyanto. 2009. Mendesain Model Pembelajaran Inovatif dan Prograsif. Jakarta: Kencana.

Wina Sanjaya. 2008. Strategi Pembelajaran. Jakarta: Kencana. 